\title{
Development, printability and post-curing studies of formulations of materials resistant to microbial attachment for use in inkjet based 3D printing
}

\author{
Belen Begines \\ 3D Printing Research Group, University of Nottingham, Nottingham, UK \\ Andrew L. Hook and Morgan R. Alexander \\ Laboratory of Biophysics and Surface Analysis, University of Nottingham, Nottingham, UK, and \\ Christopher F. Tuck and Ricky D. Wildman \\ 3D Printing Research Group, University of Nottingham, Nottingham, UK
}

\begin{abstract}
Purpose - This paper aims to print 3D structures from polymers that resist bacterial attachment by reactive jetting of acrylate monomers. Design/methodology/approach - The first step towards printing was ink development. Inks were characterised to carry out an estimation of their potential printability using the Z parameter to predict stable jetting conditions. Printability conditions were optimised for each ink using a Dimatix DMP-2800, which enabled 3D structures to be fabricated.

Findings - UV photo-initiated polymers, which resist bacterial attachment, were found to be printable using piezo-based inkjet printers. The waveform required for each ink depends on the value of the Z parameter. Once the waveform and the printability parameters were optimised, 3D objects were fabricated.

Research limitations/implications - This methodology has been confirmed as an effective method to 3D print materials that have been demonstrated to be bacteria resistant. However, ink curing depends on modification of some parameters (such as photoinitiator concentration or UV exposure time) which would result in an improvement of the curing process post jetting.

Social implications - The combination of inkjet based 3D printing with new materials resistant to bacterial attachment means the possibility of building customised medical devices with a high level of complexity and bespoke features can be fully realised. The scope and variability of the devices produced will exceed what can be achieved using standard fabrication methodologies and can be applied to reduce the incidence of device associated infections and to address increased morbidity, mortality and health care costs associated with nosocomial infections.

Originality/value - In this paper, the novel use of materials that resist bacterial attachment has been described to build 3D structures using material jetting. Its value lies on the potential impact this methodology could produce in the biomedical device and research fields.
\end{abstract}

Keywords 3D printing, Inkjet, Antibacterial monomers, UV curable monomers

Paper type Research paper

\section{Introduction}

Currently, one of the major problems encountered by clinicians is the high percentage of infections caused by bacterial biofilms that form on indwelling medical devices such as tubes used as catheters, for breathing and feeding. These surface dwelling microbial colonies develop up to 1,000 times higher tolerances to antibiotic treatment and the host immune system compared with their planktonic counterparts (Costerton et al., 1999; Smith, 2005). Most current strategies targeted at the reduction of biofilm-associated infections focus

The current issue and full text archive of this journal is available on Emerald Insight at: www.emeraldinsight.com/1355-2546.htm

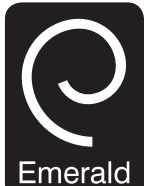

Rapid Prototyping Journa

22/5 (2016) 835-841

Emerald Emerald Group Publishing Limited [ISSN 1355-2546]

[DOI 10.1108/RPJ-11-2015-0175] on the modification of existing materials used to manufacture medical devices using approaches such as the incorporation of antibiotics (Darouiche et al., 1999) or other antimicrobials, such as silver salts, nitrofurazone, chlorhexidine, polymerized quaternary ammonium surfactants, antibacterial peptides and anionic nanoporous hydrogels (Yorganci et al., 2002; Jaeger et al., 2001; Guay, 2001; Caillier et al., 2009; Li et al., 2011; Costa et al., 2011). These natural or synthetic chemicals aim to kill bacteria that attach or approach the device surface. The mechanisms of action of these drugs are mainly based on their

(C) The authors. This article is published under the Creative Commons Attribution (CC BY 3.0) licence. Anyone may reproduce, distribute, translate and create derivative works of this article (for both commercial and non-commercial purposes), subject to full attribution to the original publication and authors. The full terms of this licence may be seen at http:// creativecommons.org/licences/by/3.0/legalcode.

The authors kindly acknowledge the EPSRC for funding this project.

Received 18 November 2015

Accepted 28 November 2015 
interaction with the bacterial metabolism, either destroying the integrity of the cellular membrane as interfering with any of the steps of protein replication or even crossing the nuclear membrane to join DNA. An alternative approach is to use materials that inherently resist biofilm formation in the first place (Monds and O'Toole, 2009). Poly(ethylene glycol) brushes (Holmes et al., 2009) and zwitterionic polymers (Cheng et al., 2007) act to modify the surface, usually altering the form presented or the energy state. Unfortunately, the addition of these coatings to reduce fouling eventually fails as the surface ages. Other materials are therefore sought, with one method of identifying candidates being high throughput screening. High throughput screening has been used to identify a new class of materials resistant to bacterial attachment by creating copolymer combinations of readily available acrylates, depositing these new materials in arrays and characterising the interaction between bacteria and the surface (Hook et al., 2012, 2013). The weakly amphiphilic acrylates discovered prevent attachment of bacteria and therefore inhibit biofilm formation in vitro and in vivo and consequently, offer the potential for the reduction of device-centred infections.

An additional facet of these materials, inherent in their identification, is that these monomers are readily cured when illuminated with UV light and when in the presence of suitable photoinitiators. This places these materials in a position where it may be possible to form useful objects from them using $3 \mathrm{D}$ printing (3DP)-based techniques. 3DP requires a method of "triggering" a phase change, usually from liquid to solid, and UV initiated curing is a commonly used approach.

In the field of biomedical applications, 3DP has become popular, but has typically utilised the techniques of extrusion or laser sintering (Chia and Wu, 2015; Thomas et al., 2014). However, inkjet printing opens the door to the utilization of multiple fluid inks for multifunctional 3DP, and allowing for the use of new polymers outside the range of the workable polymeric materials used in extrusion and laser sintering. Other advantages of inkjet printing are its mechanism of drop-on-demand (DOD) deposition, which increases the versatility of the process including precise positioning of pico-litre sized drops.

Thus, the combination of materials resistant to bacterial attachment with the versatility of inkjet printing could realise the production of objects with surfaces that resist bacterial attachment, in a single manufacturing step. This paper describes the development and optimization of three materials recently identified as resisting bacterial attachment specifically for DOD inkjet printing and the demonstration of the ability to form three dimensional structures from these materials.

\section{Materials and methods}

The target monomers were selected from the range of acrylate- and methacrylate- derivatives showing the most promising results as bacterial resistant materials (Hook et al., 2012, 2013). The results for this selection were: Ethylene glycol dicyclopentenyl ether acrylate (monomer A), Tricyclo $\left[5 \cdot 2 \cdot 1.0^{2,6}\right]$ decanedimethanol diacrylate (monomer B) and 2-Ethylhexyl acrylate (monomer C) (Scheme 1).

DOD droplet generation requires fluids with certain physical and mechanical characteristics (Derby, 2010). These
Scheme 1 Chemical structure of printed monomers

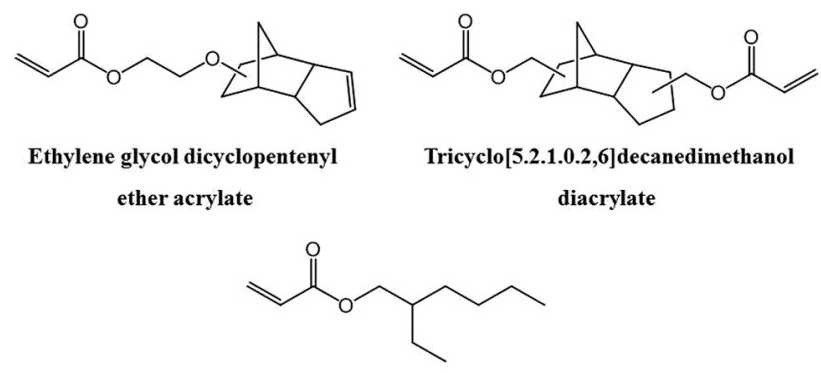

2-Ethylhexyl acrylate

characteristics are reflected in different dimensionless groupings of physical constants, the most useful of which are the Reynolds (Re) [equation (1)], Weber (We) [equation (2)] and Ohnesorge (Oh) [equation (3)] numbers:

$$
\begin{gathered}
R e=\frac{v \rho r}{\mu} \\
W e=\frac{v^{2} \rho r}{\gamma} \\
O h=\frac{\sqrt{W e}}{R e}
\end{gathered}
$$

where $v$ is the velocity, $r$ is the nozzle diameter and $\rho, \mu$ and $\gamma$ are the density, dynamic viscosity and surface tension of the fluid, respectively.

Fromm (1984) defined the $Z$ parameter (or printability indicator) as the appropriate constant to determine the printability of a given fluid:

$$
Z=\frac{1}{O h}=\frac{\sqrt{\rho r \gamma}}{\mu}
$$

Building on this concept, Reis and Derby (2000) used numerical simulation of drop formation to propose that the range for stable droplet formation should be $1<Z<10$. As a consequence to guide identification of the "ejectability" of the candidate $3 \mathrm{DP}$ materials, $Z$ was measured for each of the target monomers.

Monomers and initiator were purchased from Aldrich Chemical Co. and used as received. To initiate photopolymerisation, photoinitiators were required, and in this case 2,2-Dimethoxy-2-phenylacetophenone (DMPA) was used. Rheological data were collected from 25 to $60^{\circ} \mathrm{C}$ or $70^{\circ} \mathrm{C}$, while the surface tension was measured at each of the corresponding printing temperatures or in a range from 25 to $60^{\circ} \mathrm{C}$. A Malvern Kinexus Pro Rheometer equipped with a cone and plate, or a parallel plate at $400 \mu \mathrm{m}$ separation, was used for viscosity measurement under shear rates from $10 \mathrm{~s}^{-1}$ and $1,000 \mathrm{~s}^{-1}$. Each measurement started at $25^{\circ} \mathrm{C}$ with $5^{\circ} \mathrm{C}$ increments up to 60 or $70^{\circ} \mathrm{C}$, the precise increments depending on the monomer. A protocol of waiting $300 \mathrm{~s}$ after reaching the test temperature was set to ensure the ink was in a steady state condition. At each temperature point and shear rate, the viscosity was recorded at $5 \mathrm{~s}$ intervals within a $180 \mathrm{~s}$ test time. For the determination of surface tension, a Kruss 
DSA100S was used, applying the pendant drop method assisted by the Young-Laplace equation (Berry et al., 2015). Density values of pure monomers were used, as density variations at low levels of photoinitiator addition were insignificant. All inks were prepared by mixing 1 per cent of DMPA, as photoinitiator, with the corresponding monomer, using amber vials. To help the solution, the mixture was placed on a stirrer (IKA RCT Basic IKAMAG Magnetic Stirrer, with Temperature Controller) for $10 \mathrm{~min}$ at $50^{\circ} \mathrm{C}$. A flow of $\mathrm{N}_{2}$ was applied to the mixture for $10 \mathrm{~min}$ for degassing. Inks were kept in the dark for two days to enable the release of bubbles. Printability tests were carried out in a FujiFilm Dimatix DMP-2800. The cartridges used in the experiments were characterised for a $21 \mu \mathrm{m}$ nozzle diameter.

To produce $3 \mathrm{D}$ printed samples a Dimatix DMP2800 was installed inside a glovebox with an $\mathrm{O}_{2}$ sensor. $\mathrm{A} \mathrm{N}_{2}$ flow was circulated until the $\mathrm{O}_{2}$ level was less than 1 per cent. A UV light $\left(365 \mathrm{~nm}, 3.5 \mathrm{~J} / \mathrm{cm}^{2}\right)$ was assembled on to the Dimatix printhead carriage to carry out sample curing while printing.

To assess the relationship between the roughness of printed surfaces and spacing between successive droplets, $2 \times 2 \mathrm{~mm}$ square structures were printed with curable inks at increasing drop spacing $(20,30,40$ and $50 \mu \mathrm{m})$ and with increasing number of layers (2, 4, 6, 8 and 10) of material. Surface profiles were obtained using a Bruker Contour GT-K Interferometer, equipped with a $5 \times$ lens amplified $2 \times$. Vision $64^{\mathrm{TM}}$ software was used to analyse images, obtaining the values for average height, mean roughness $\left(R_{a}\right)$ and mean roughness depth $\left(R_{z}\right)$ for each number of layers and drop spacing. The average height of one layer was estimated by linear regression.

\section{Results and discussion}

The viscosity for inks A and B are shown in Figures 1 and 2. For acrylate C, data found in the literature (Arkema, 2015) were $1.5 \mathrm{mPa} \mathrm{s}\left(25^{\circ} \mathrm{C}\right)$. This value is too low to obtain reliable measurement with the geometries currently available in the lab, and no further rheological assessment of this material was conducted. The manufacturer's guidelines for printing with the Dimatix DMP2800 suggest an ideal viscosity of $10 \mathrm{mPa} . \mathrm{s}$ and as a consequence printing temperatures of 40 and $70^{\circ} \mathrm{C}$ for

Figure 1 Viscosity data as a function of shear rate and temperature for ink $A$

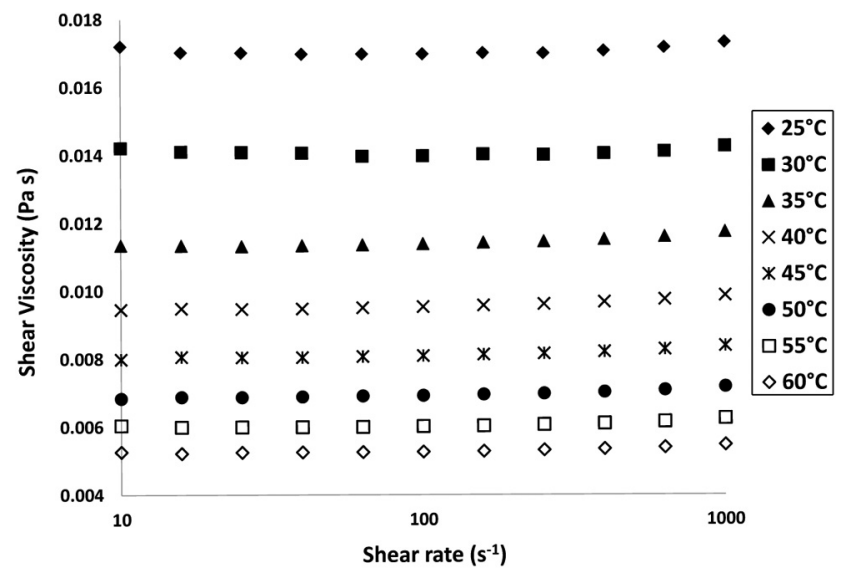

Figure 2 Viscosity data as a function of shear rate and temperature for ink $\mathrm{B}$

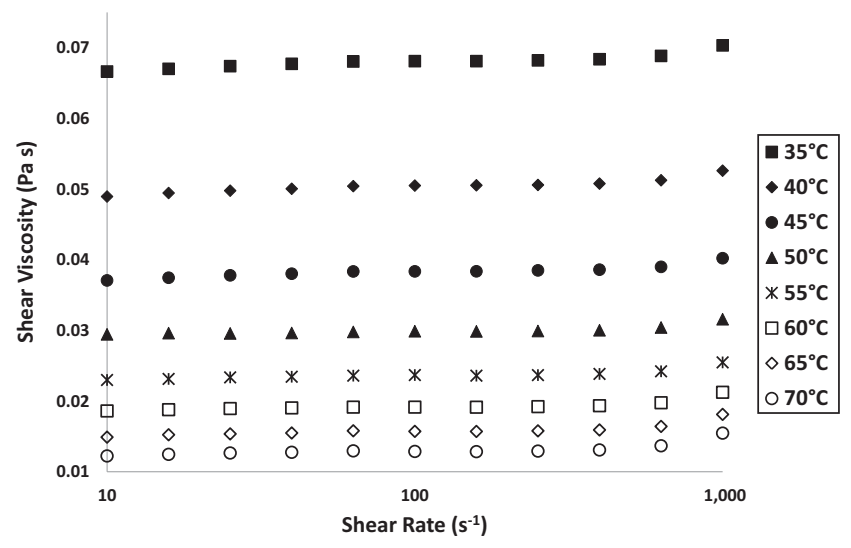

inks A and B were selected, respectively. The corresponding viscosity values are shown in Table I.

The surface tension of inks A and C were measured directly at their printing temperature. However, the printing temperature of ink B was $70^{\circ} \mathrm{C}$, higher than the maximum operating temperature of the Kruss DSA100S. Due to this measurement issue, the value of the surface tension of ink B at such a temperature was then estimated by extrapolation using the Guggenheim-Katayama equation (5) (Guggenheim, 1945), which defines the relationship surface tension-temperature of interfaces:

$$
\gamma=\gamma^{\circ}\left(1-\frac{T}{T c}\right)^{\frac{11}{9}}
$$

Figure 3 shows the model from equation (5) fitting to the experimental results, obtained by measuring the surface tension

Table I Values of printing temperature, shear viscosity, surface tension and density for each monomer

\begin{tabular}{lccccc}
\hline Ink & $\begin{array}{c}\text { Temperature } \\
\left({ }^{\circ} \mathrm{C}\right)\end{array}$ & $\begin{array}{c}\text { Shear } \\
\text { viscosity } \\
(\mathrm{mPa})\end{array}$ & $\begin{array}{c}\text { Surface } \\
\text { tension } \\
(\mathbf{m N} / \mathbf{m})\end{array}$ & $\begin{array}{c}\text { Density } \\
(\mathbf{g} / \mathbf{m l})\end{array}$ & $\begin{array}{c}\mathbf{Z} \\
\text { Parameter }\end{array}$ \\
\hline A & 40 & 9.4 & $36.5 \pm 0.2$ & 1.09 & 3.1 \\
B & 70 & 12.9 & $30.0 \pm 0.1$ & 1.1 & 2.0 \\
C & 25 & 1.5 & $25.9 \pm 0.1$ & 0.89 & 15.7 \\
\hline
\end{tabular}

Figure 3 Surface tension of ink B

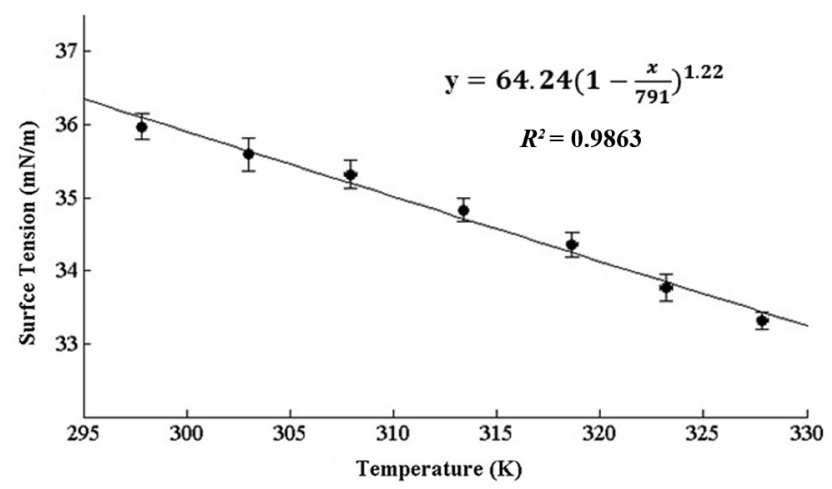


of ink B at different temperatures. This generates values for $\gamma^{\circ}$ and $\mathrm{T}_{\mathrm{c}}$ of $64.24 \mathrm{mN} / \mathrm{m}$ and $791 \mathrm{~K}$, respectively. At $343 \mathrm{~K}\left(70^{\circ} \mathrm{C}\right)$, it is possible from this curve to estimate a value of $32.1 \mathrm{mN} / \mathrm{m}$ for the surface tension of ink $B$ at the preferred printing temperature.

A constant value of density with temperature and minor addition of photoinitiator was taken and assumed to be equal to the density of the monomers.

The printability parameter was calculated for each acrylate from the values obtained for viscosity and surface tension, the pure monomer density and a nozzle diameter of $21 \mu \mathrm{m}$ (Table I). These data demonstrate that inks $\mathrm{A}$ and $\mathrm{B}$, displaying $\mathrm{Z}$ values of 3 and 2.1, respectively, are printable and afford a stable droplet generation (Figure 4). A Z parameter of 15.7 for $\mathrm{C}$ was noted, indicating unreliable printing was likely. In Figure 5, the standard waveform for printing inks A and B is shown. Although C was not expected to be printable, stable droplet generation was achieved through the adoption of a more complex wave form
(Figures 4 and 5). A summary table showing printing parameters such as printing temperature, voltage and jetting frequency are shown in Table II.

Once the printability parameters were optimised, an investigation of the relationship between drop spacing, height and roughness for inks $\mathrm{A}$ and $\mathrm{B}$ was assessed using polyethylene terephthalate as the substrate (Table III and Table IV).

Figure 6 shows the structure height as a function of the number of layers printed and the drop spacing used for ink A. Layer thickness (a), together with its standard error (SE) and coefficient of determination $\left(R^{2}\right)$ at each drop spacing are shown in Table V. Measures of roughness, $R_{a}$ and $R_{z}$, were used as measures of film quality. These indicate that above $30 \mu \mathrm{m}$ drop spacing the roughness increases markedly, suggesting $30 \mu \mathrm{m}$ or below is optimal.

These experiments were repeated for ink B (Figure 7). Layer thickness was slightly thinner than that observed for ink

Figure 4 (a) Sequence of droplet formation of ink A with standard waveform; (b) sequence of droplet formation of ink C with complex waveform
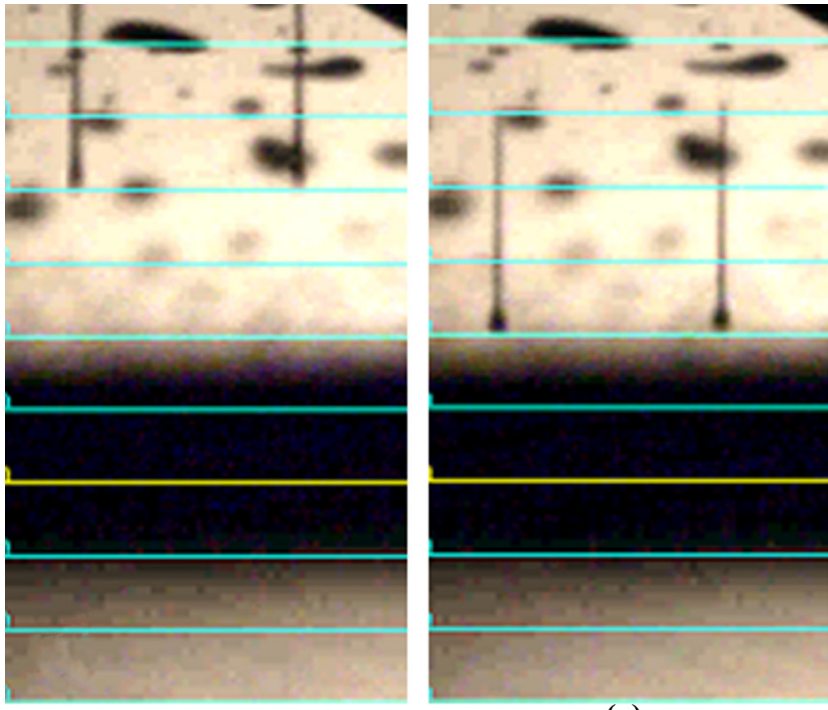

(a)
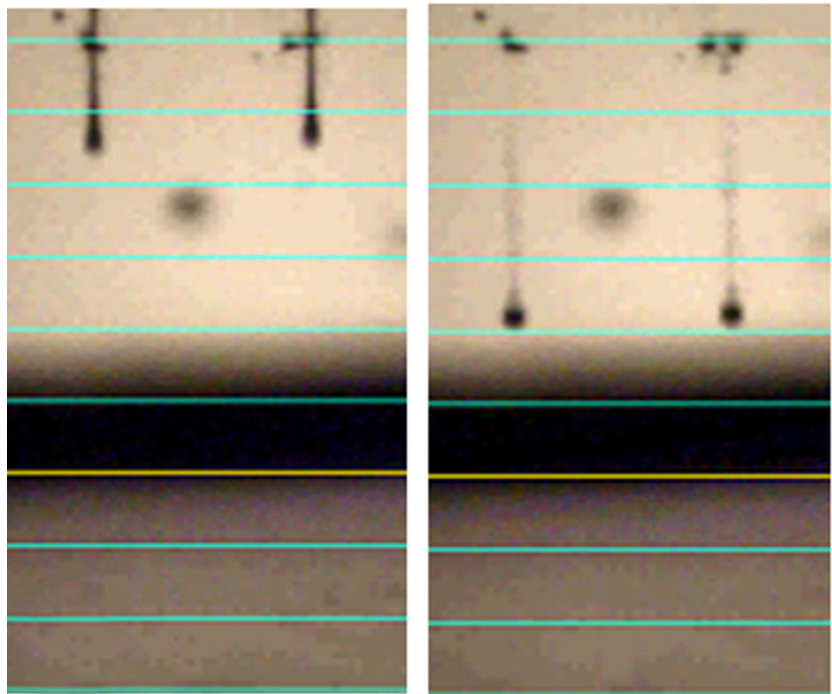

(b)
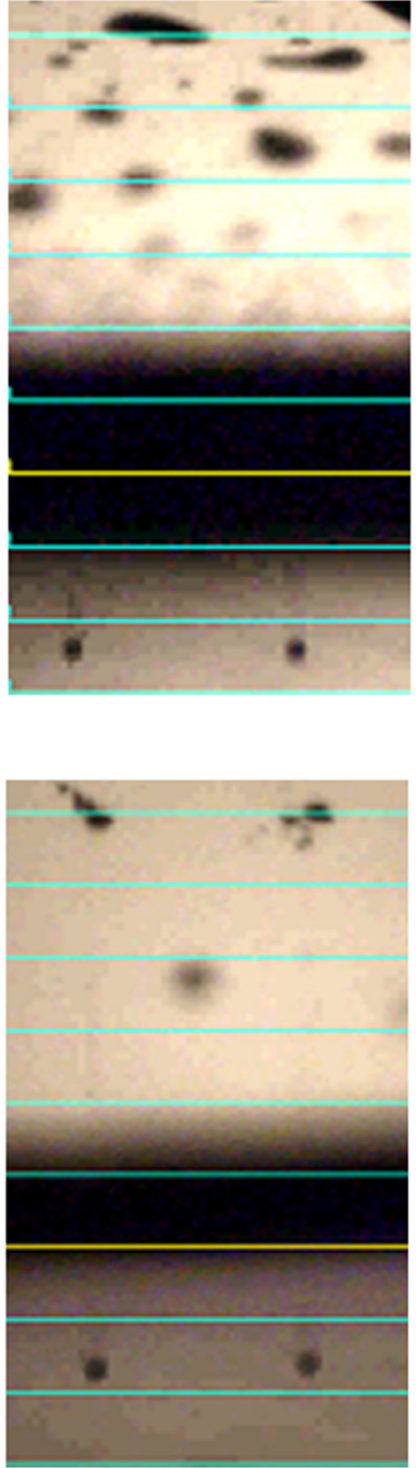
Figure 5 (a) Standard waveform used for printing inks A and B; (b) complex waveform used for ink C

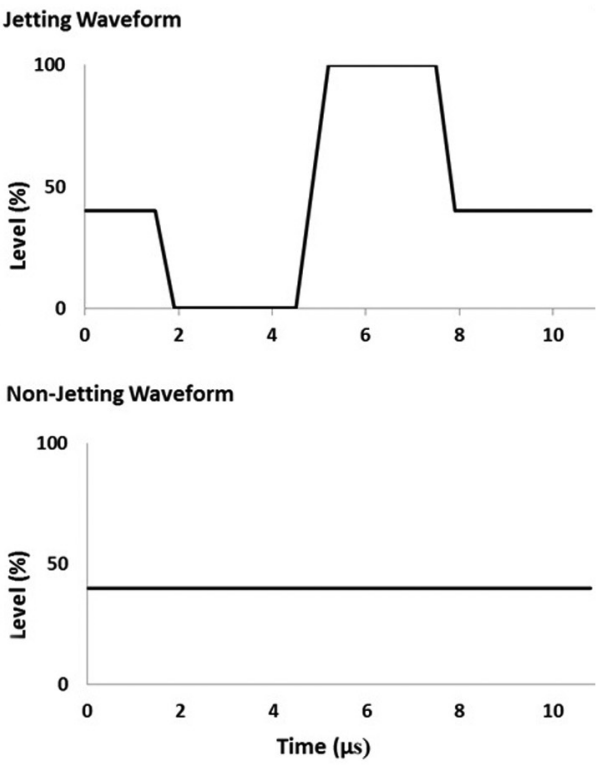

(a)

Table II Printing parameters for each ink

\begin{tabular}{lccc}
\hline Inks & Printing temperature $\left({ }^{\circ} \mathrm{C}\right)$ & Voltage $(\mathrm{v})$ & Jetting frequency $(\mathrm{KHz})$ \\
\hline A & 40 & $19-20$ & 3 \\
B & 70 & $19-21$ & 6 \\
C & 25 & $18-19$ & 1 \\
\hline
\end{tabular}

A (Table V). The roughness measurements indicate that for this material, a drop spacing of $40 \mu \mathrm{m}$ was optimal, producing the lowest roughness, and one that reduces significantly as more layers of material are added. In
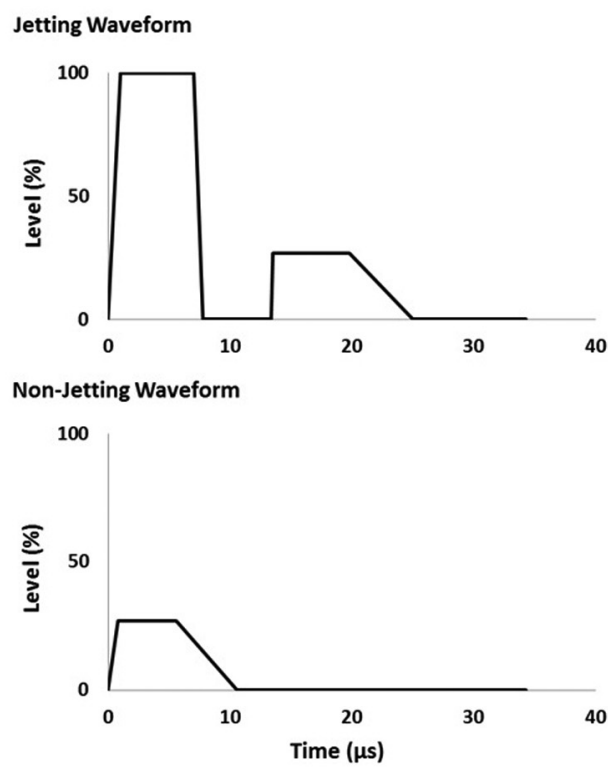

(b)

contrast to ink $\mathrm{A}$, however, at the largest drop spacing, increasing numbers of layers decreases the quality; the roughness values at $50 \mu \mathrm{m}$ droplet spacing rise with increasing numbers of layers.

Despite the promise offered by ink $\mathrm{C}$ in showing stable droplet formation, it was not possible to cure the material within the jetting and illumination parameters available. Therefore, demonstrator 3D structures were built with inks $\mathrm{A}$ and $\mathrm{B}$ only, using the printing conditions above. A drop spacing of $30 \mu \mathrm{m}$ was used. Two example structures are shown in Figures 8 and 9, demonstrating that it was possible to print,

Table III Values of height, $R_{a}$ and $R_{z}$ as a function of the drop spacing used for printing and the number of layers printed for ink $A$

\begin{tabular}{|c|c|c|c|c|c|c|c|c|c|c|c|c|}
\hline \multirow{2}{*}{ No. of layers spacing } & \multicolumn{3}{|c|}{$20 \mu \mathrm{m}$} & \multicolumn{3}{|c|}{$30 \mu \mathrm{m}$} & \multicolumn{3}{|c|}{$40 \mu \mathrm{m}$} & \multicolumn{3}{|c|}{$50 \mu \mathrm{m}$} \\
\hline & $\begin{array}{l}\text { Average } \\
\text { height } \\
(\mu \mathrm{m})\end{array}$ & $\begin{array}{c}R_{\mathrm{a}} \\
(\mu \mathrm{m})\end{array}$ & $\begin{array}{c}\mathrm{R}_{\mathrm{z}} \\
(\mu \mathrm{m})\end{array}$ & $\begin{array}{l}\text { Average } \\
\text { height } \\
(\mu \mathrm{m})\end{array}$ & $\begin{array}{c}\mathrm{R}_{\mathrm{a}} \\
(\mu \mathrm{m})\end{array}$ & $\begin{array}{c}\mathrm{R}_{\mathrm{z}} \\
(\mu \mathrm{m})\end{array}$ & $\begin{array}{c}\text { Average } \\
\text { height } \\
(\mu \mathrm{m})\end{array}$ & $\begin{array}{c}R_{\mathrm{a}} \\
(\mu \mathrm{m})\end{array}$ & $\begin{array}{c}\mathrm{R}_{\mathrm{z}} \\
(\mu \mathrm{m})\end{array}$ & $\begin{array}{c}\text { Average } \\
\text { height } \\
(\mu \mathrm{m})\end{array}$ & $\begin{array}{c}\mathrm{R}_{\mathrm{a}} \\
(\mu \mathrm{m})\end{array}$ & $\begin{array}{c}\mathrm{R}_{\mathrm{z}} \\
(\mu \mathrm{m})\end{array}$ \\
\hline 2 & 34.1 & 0.2 & 0.6 & 16.5 & 0.1 & 0.5 & 8.4 & 1.1 & 5.6 & 6.8 & 2.1 & 10 \\
\hline 4 & 71.1 & 0.1 & 0.5 & 33 & 0.2 & 0.6 & 17.9 & 1.2 & 6.2 & 12.1 & 1.9 & 9.2 \\
\hline 6 & 108.9 & 0.2 & 1.1 & 49.5 & 0.2 & 0.8 & 26.7 & 1.8 & 10.1 & 15 & 1.8 & 9.1 \\
\hline 8 & 145 & 0.2 & 0.8 & 67.4 & 0.1 & 0.7 & 35.9 & 1.5 & 8 & 21.8 & 1.7 & 8.7 \\
\hline 10 & 178.2 & 0.2 & 0.7 & 81.8 & 0.1 & 0.6 & 43.2 & 1.7 & 9.7 & 27.3 & 1.1 & 5.4 \\
\hline
\end{tabular}

Table IV Values of height, $R_{a}$ and $R_{z}$ as a function of the drop spacing used for printing and the number of layers printed for ink $B$

\begin{tabular}{|c|c|c|c|c|c|c|c|c|c|c|c|c|}
\hline \multirow{2}{*}{ No. of layers } & \multicolumn{3}{|c|}{$20 \mu \mathrm{m}$} & \multicolumn{3}{|c|}{$30 \mu \mathrm{m}$} & \multicolumn{3}{|c|}{$40 \mu \mathrm{m}$} & \multicolumn{3}{|c|}{$50 \mu \mathrm{m}$} \\
\hline & $\begin{array}{l}\text { Average } \\
\text { height } \\
(\mu \mathrm{m})\end{array}$ & $\begin{array}{c}\mathbf{R}_{\mathrm{a}} \\
(\mu \mathrm{m})\end{array}$ & $\begin{array}{c}\mathbf{R}_{\mathrm{z}} \\
(\mu \mathrm{m})\end{array}$ & $\begin{array}{l}\text { Average } \\
\text { height } \\
(\mu \mathrm{m})\end{array}$ & $\begin{array}{c}R_{a} \\
(\mu \mathrm{m})\end{array}$ & $\begin{array}{c}\mathbf{R}_{\mathrm{z}} \\
(\mu \mathrm{m})\end{array}$ & $\begin{array}{c}\text { Average } \\
\text { height } \\
(\mu \mathrm{m})\end{array}$ & $\begin{array}{c}\mathrm{R}_{\mathrm{a}} \\
(\mu \mathrm{m})\end{array}$ & $\begin{array}{c}\mathrm{R}_{\mathrm{z}} \\
(\mu \mathrm{m})\end{array}$ & $\begin{array}{l}\text { Average } \\
\text { height } \\
(\mu \mathrm{m})\end{array}$ & $\begin{array}{c}\mathrm{R}_{\mathrm{a}} \\
(\mu \mathrm{m})\end{array}$ & $\begin{array}{c}\mathbf{R}_{\mathrm{z}} \\
(\mu \mathrm{m})\end{array}$ \\
\hline 2 & 30.7 & 0.4 & 2 & 14.9 & 0.3 & 1.7 & 9.2 & 0.4 & 1.9 & 5 & 0.8 & 3.5 \\
\hline 4 & 61 & 0.4 & 2.3 & 29.2 & 0.3 & 1.7 & 16.7 & 0.3 & 1.4 & 10 & 1.4 & 8.5 \\
\hline 6 & 87.7 & 0.3 & 1.4 & 44.6 & 0.3 & 1.8 & 24.5 & 0.2 & 1.3 & 15 & 1.4 & 8 \\
\hline 8 & 115.9 & 0.4 & 1.8 & 58.7 & 0.3 & 1.2 & 31.6 & 0.2 & 1.3 & 19.9 & 1.3 & 8.5 \\
\hline 10 & 145.6 & 0.3 & 1.4 & 70.6 & 0.2 & 1.5 & 39.4 & 0.2 & 1 & 25.3 & 1.2 & 10.1 \\
\hline
\end{tabular}


Figure 6 Height of print versus number of layers at different drop spacing for ink $A$

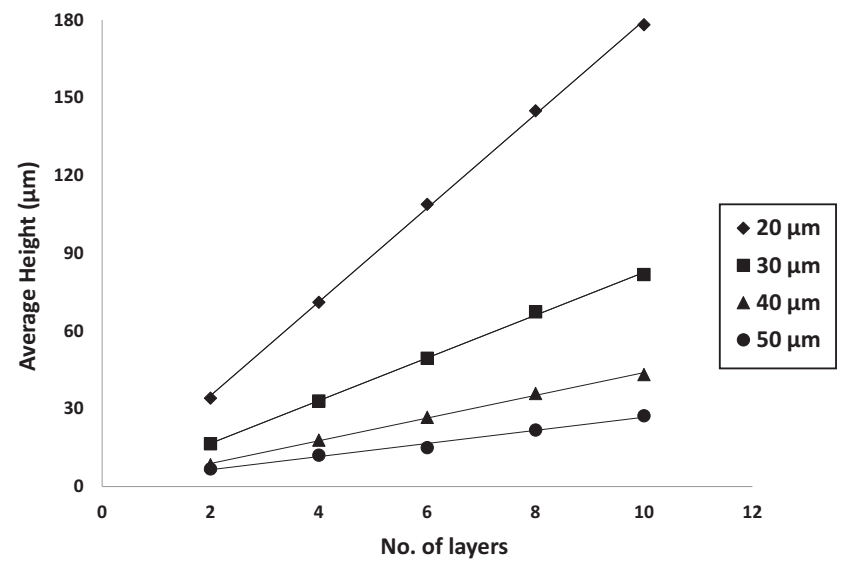

Table V Regression line parameters calculated for inks A and B

\begin{tabular}{lllllllll}
\hline & \multicolumn{4}{c}{ Ink $\mathrm{C}$} & \multicolumn{4}{c}{ Ink B } \\
& $\mathbf{2 0} \boldsymbol{\mu \mathrm { m }}$ & $\mathbf{3 0} \boldsymbol{\mu \mathrm { m }}$ & $\mathbf{4 0} \boldsymbol{\mu \mathrm { m }}$ & $\mathbf{5 0} \boldsymbol{\mu \mathrm { m }}$ & $\mathbf{2 0} \boldsymbol{\mu \mathrm { m }}$ & $\mathbf{3 0} \boldsymbol{\mu \mathrm { m }}$ & $\mathbf{4 0} \boldsymbol{\mu \mathrm { m }}$ & $\mathbf{5 0} \boldsymbol{\mu m}$ \\
\hline $\mathrm{a}(\boldsymbol{\mu m})$ & 18.1 & 8.25 & 4.38 & 2.54 & 14.2 & 7.05 & 3.77 & 2.53 \\
$\mathrm{SE}_{\mathrm{a}}(\boldsymbol{\mu m})$ & 0.3 & 0.14 & 0.11 & 0.17 & 0.2 & 0.18 & 0.03 & 0.02 \\
$\mathrm{R}^{2}$ & 0.9994 & 0.9991 & 0.9981 & 0.9872 & 0.9996 & 0.9981 & 0.9998 & 0.9997
\end{tabular}

Figure 7 Height of print versus number of layers at different drop spacing for ink $B$

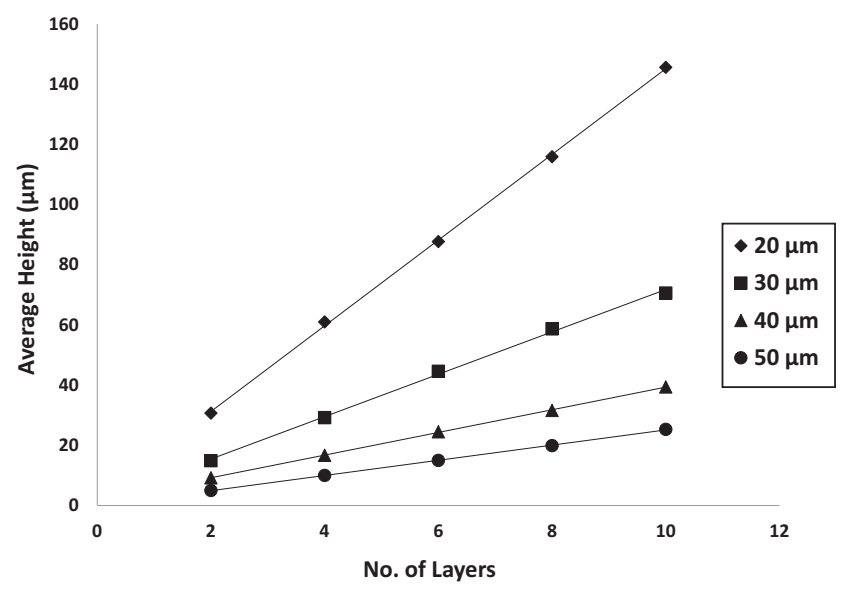

cure and form 3D structures with materials previously shown to resist bacterial attachment. Further inquiry is needed to establish the maintenance of this property through the printing process and film formation.

\section{Conclusions}

Three inks from three different monomers with resistance to bacterial attachment were chosen as candidate materials for 3DP. Printability was determined via $\mathrm{Z}$ parameter, which proved to be a reliable guide to the formation of a stable droplet. However, manipulation of the pressure wave profiles that enable drop formation afforded hitherto unprintable ink $C$ to be ink jet printed. Unfortunately, this ink was subsequently found to be slow curing and unable to processed
Figure $83 D$ structure built with ink $A$

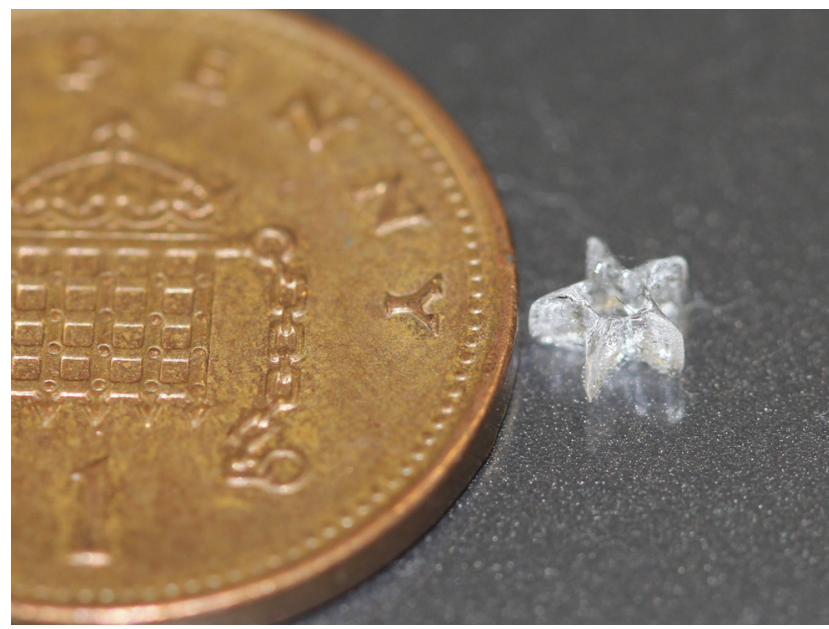

Figure $93 \mathrm{D}$ structure built with ink $B$

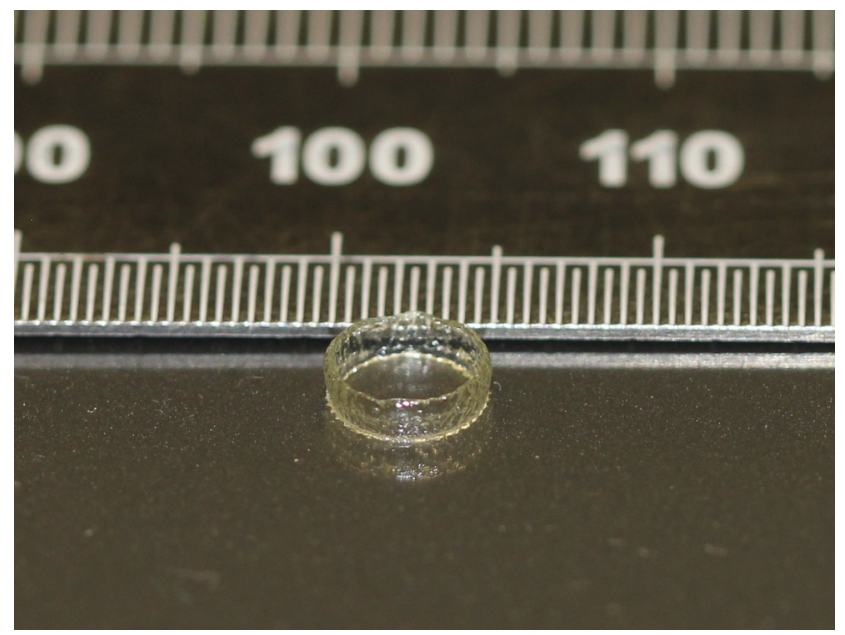

within the available parameters. An assessment of the quality of film formation using roughness measurements established a range of optimal drop spacings, leading to the formation of 3D printed objects, formed from materials previously shown to resist bacterial attachment.

\section{References}

Arkema (2015), "Norsocryl ${ }^{2} 2 \mathrm{EHA}$, available at: www.arkema. com/export/shared/.content/media/downloads/productsdocumentations/acrylicmonomers/data-sheet-norsocryl-2eha. pdf

Berry, J.D., Neeson, M.J., Dagastine, R.R., Chan, D.Y.C. and Tabor, R.F. (2015), "Measurement of surface and interfacial tension using pendant drop tensiometry", fournal of Colloid and Interface Science, Vol. 454, pp. 226-237.

Caillier, L., de Givenchy, E.T., Levy, R., Vandenberghe, Y., Géribaldi, S. and Guittard, F. (2009), "Synthesis and antimicrobial properties of polymerizable quaternary ammoniums", European fournal of Medical Chemistry, Vol. 44, pp. 3201-3208.

Cheng, G., Zhang, Z., Chen, S.F., Bryers, J.D. and Jiang, S.Y. (2007), "Inhibition of bacterial adhesion and biofilm 
formation on zwitterionic surfaces", Biomaterials, Vol. 28 No. 29, pp. 4192-4199.

Chia, H.N. and Wu, B.M. (2015), "Recent advances in 3D printing of biomaterials", fournal of Biological Engineering, Vol. 9 No. 4

Costa, F., Carvalho, I.F., Montelaro, R.C., Gomes, P. and Martins, M.C.L. (2011), "Covalent immobilization of antimicrobial peptides (AMPs) onto biomaterial surfaces", Acta Biomaterialia, Vol. 7 No. 4, pp. 1431-1440.

Costerton, J.W., Stewart, P.S. and Greenberg, E.P. (1999), "Bacterial biofilms: a common cause of persistent infections", Science, Vol. 284 No. 5418, pp. 1318-1322.

Darouiche, R.O., Raad, I.I., Heard, S.O., Thornby, J.I., Wenker, O.C., Gabrielli, A., Berg, J., Khardori, N., Hanna, H., Hachem, R., Harris, R.L. and Mayhall, G. (1999), "A comparison of two antimicrobial-impregnated central venous catheters", New England Fournal of Medicine, Vol. 340, pp. 1-8.

Derby, B. (2010), "Inkjet printing of functional and structural materials: fluid property requirements, feature stability and resolution", Annual Review of Material Research, Vol. 40, pp. 395-414.

Fromm, J.E. (1984), "Numerical calculation of the fluid dynamics of drop-on-demand jets", IBM fournal of Research and Development, Vol. 28 No. 3, pp. 322-333.

Guay, D.R. (2001), "An update on the role of nitrofurans in the management of urinary tract infections", Drugs, Vol. 61 No. 3, pp. 353-364.

Guggenheim, E.A. (1945), "The principle of corresponding states”, Fournal of Chemical Physics, Vol. 13 No. 7, p. 253.

Holmes, P.F., Currie, E.P.K., Thies, J.C., Van Der Mei, H.C., Busscher, H.J. and Norde, W. (2009), "Surface-modified nanoparticles as a new, versatile, and mechanically robust nonadhesive coating: suppression of protein adsorption and bacterial adhesion", foumal Biomedical Material Research Part A, Vol. 91 No. 3, pp. 824-833.

Hook, A.L., Chang, C.Y., Yang, J., Atkinson, S., Langer, R., Anderson, D.G., Davies, M.C., Williams, P. and Alexander, M.R. (2013), "Discovery of novel materials with broad resistance to bacterial attachment using combinatorial polymer microarrays", Advanced Materials, Vol. 25 No. 18, pp. 2542-2547.
Hook, A.L., Chang, C.Y., Yang, J., Luckett, J., Cockayne, A., Atkinson, S., Mei, Y., Bayston, R., Irvine, D.J., Langer, R., Anderson, D.G., Williams, P., Davies, M.C. and Alexander, M.R. (2012), "Combinatorial discovery of polymers resistant to bacterial attachment", Nature Biotechnology, Vol. 30 No. 9, pp. 868-875.

Jaeger, K., Osthaus, A., Heine, J., Ruschulte, H., Kuhlmann, C., Weissbrodt, H., Ganser, A. and Karthaus, M. (2001), "Efficacy of a benzalkonium chloride-impregnated central venous catheter to prevent catheter-associated infection in cancer patients", Chemotherapy, Vol. 47 No. 1, pp. 50-55.

Li, P., Poon, Y.F., Li, W., Zhu, H.Y., Yeap, S.H., Cao, Y., Qi, X., Zhou, C., Lamrani, M., Beuerman, R.W., Kang, E.T., Mu, Y., Li, C.M., Chang, M.W., Leong, S.S.J. and Chan-Park, M.B. (2011), "A polycationic antimicrobial and biocompatible hydrogel with microbe membrane suctioning ability", Nature Materials, Vol. 10 No. 2, pp. 149-156.

Monds, R.D. and O'Toole, G.A. (2009), “The developmental model of microbial biofilms: ten years of a paradigm up for review", Trends in Microbiology, Vol. 17 No. 2, pp. 73-87.

Reis, N. and Derby, B. (2000), "Ink jet deposition of ceramic suspensions: modeling and experiments of droplet formation", MRS Proceedings, Vol. 624, p. 65-70.

Smith, W. (2005), "Biofilms and antibiotic therapy: is there a role for combating bacterial resistance by the use of novel drug delivery systems?", Advanced Drug Delivery Review, Vol. 57 No. 10, pp. 1539-1550.

Thomas, D.J., Mohd Azmi, M.A.B. and Tehrani, Z. (2014), " $3 \mathrm{D}$ additive manufacture of oral and maxillofacial surgical models for preoperative planning", International fournal of Advanced Manufacturing Technology, Vol. 71 No. 9, pp. 1643-1651.

Yorganci, K., Krepel, C., Weigelt, J.A. and Edmiston, C.E. (2002), "Activity of antibacterial impregnated central venous catheters against Klebsiella pneumoniae", Intensive Care Medicine, Vol. 28 No. 4, pp. 438-442.

\section{Corresponding author}

Belen Begines can be contacted at: belen.begines@ nottingham.ac.uk 